\title{
Design Performance Assessment of Fire Alarm System based on Principal Components Analysis
}

\author{
Lan Zhenliang, Qu Na, Zhu Mingxing
}

School of Safety Engineering, Shenyang Aerospace University, Shenyang, Liaoning 110136

Key words: fire alarm system; design performance assessment; principal components analysis

\begin{abstract}
Design performance assessment of fire alarm system is to test the design scheme of large complex fire alarm system and determine the degree of satisfaction of the system design objective. The second-grade indexes of design performance assessment of fire alarm system are extracted by principal components analysis. The paper uses SPSS16.0 and Microsoft Excel to complete the data statistics and analysis process.
\end{abstract}

\section{Introduction}

If the performance of fire alarm system is excellent, the loss of life and property caused by fire can be minimized. The performance of fire alarm system mainly includes design performance, product performance and running performance. Design performance evaluation is a large complex fire automatic alarm system design program to determine to meet the system design goals. The principal component analysis method is used to evaluate the design performance of automatic fire alarm system, which can promote the scientific and standardization of the automatic fire alarm system evaluation.

In 2011, Liu concluded that the detection time of the fire detection system under the longitudinal air condition depends on the fuel type, the size and location of the fire, the velocity of the air flow and the detection method [1]. Marty Ahrens counts the performance of the American home smoke alarm system [2]. In 2012, Zhang Z. analyzed the response performance of the fire detector, predicted the response time of the ASD system by numerical calculation, and could guide the design and installation of the ASD system of the large space building, and did not establish the effectiveness evaluation model of the automatic fire alarm system [3]. Zhang L. uses the analytic hierarchy process to determine the comprehensive weight of the third-level index of multi-criteria and constructs the effectiveness evaluation model of fire command automation system [4]. In 2014, G. Santha established a tumor analysis model using the combination of PNN and PCA[5].

Evaluation Algorithm Design. According to GB / Z24978-2010 of fire automatic alarm system performance evaluation, design performance evaluation indexes of fire alarm system include7 first-level evaluation indicators and 21secondary evaluation indicators. The evaluation method can be used to simplify the evaluation model by using the principal component analysis method to evaluate the secondary evaluation index after compression extraction.

Design Performance Evaluation Indicators. Design performance evaluation indexes of fire alarm system are shown in Table 1.

Secondary Evaluation Index Compression Extraction. Principal Component Analysis. Principal component analysis is a multivariate statistical method that examines the correlation between multiple variables. It examines how a few principal components can be used to reveal the internal structure between multiple variables, that is, a few principal components are derived from the original variables, As much as possible to retain the original variable information, and each other between each other. The specific steps are as follows:

(1)Column matrix $Y$, and the data is normalized matrix $X$;

(2) Establish the relevant matrix: $C=\frac{1}{m-1} * X^{*} X$;

(3) Calculate the correlation coefficient matrix: $R=\left[r_{i j}\right]_{p^{*} p}=\frac{X^{* * X}}{m-1}$; 
(4)Find eigenvalues and eigenvectors: $[V, D]=e i g(C)$;

(5)From large to small eigenvalues: $\lambda_{1}>\lambda_{2}>\cdots>\lambda_{m}$;

(6) Cal culate variance contribution rate (greater than 90\%): $K=\sum_{i=1}^{r} K_{i}=\sum_{i=1}^{r}\left|\lambda_{i} / \sum_{i=1}^{n} \lambda_{i}\right| * 100 \%$;

(7)For each one $\lambda_{j}, j=1,2 \cdots r$, Solution of equations $R^{*} b=\lambda_{j} * b$ unit vector $b_{j}^{0}=\frac{b_{j}}{\left\|b_{j}\right\|}$;

(8)Cal culate the principal component.

Table 1. Design performance evaluation index system

\begin{tabular}{|c|c|c|c|}
\hline First level index & Two level index & First level index & Two level index \\
\hline \multirow{4}{*}{ System integrity } & $\begin{array}{l}\text { Basic technical } \\
\text { requirements of the } \\
\text { system }\end{array}$ & \multirow{2}{*}{ Fire separation } & $\begin{array}{l}\text { Fire extinguishing } \\
\text { separation }\end{array}$ \\
\hline & $\begin{array}{l}\text { System network } \\
\text { constitution and } \\
\text { management mode }\end{array}$ & & $\begin{array}{l}\text { Fire control equipment } \\
\text { linkage control logic } \\
\text { relationship }\end{array}$ \\
\hline & System compatible & \multirow{4}{*}{$\begin{array}{l}\text { Facilities } \\
\text { monitoring }\end{array}$} & $\begin{array}{l}\text { Smoke control threshold } \\
\text { monitoring }\end{array}$ \\
\hline & $\begin{array}{l}\text { Redundancy and } \\
\text { extension of } \\
\text { controller capacity }\end{array}$ & & $\begin{array}{l}\text { Evacuation door } \\
\text { monitoring }\end{array}$ \\
\hline \multirow[t]{2}{*}{ Fire detection } & $\begin{array}{l}\text { Selection and } \\
\text { selection of fire } \\
\text { detectors }\end{array}$ & & $\begin{array}{l}\text { Fire extinguishing } \\
\text { facilities monitoring }\end{array}$ \\
\hline & $\begin{array}{l}\text { Fire trigger device } \\
\text { setting }\end{array}$ & & $\begin{array}{l}\text { Field fire power } \\
\text { monitoring }\end{array}$ \\
\hline \multirow{4}{*}{$\begin{array}{l}\text { Evacuation } \\
\text { security }\end{array}$} & $\begin{array}{l}\text { Selection of } \\
\text { evacuation linkage }\end{array}$ & \multirow{3}{*}{ External help } & $\begin{array}{l}\text { Fire danger spot } \\
\text { indication }\end{array}$ \\
\hline & $\begin{array}{l}\text { Fire alarm and } \\
\text { emergency } \\
\text { broadcast design }\end{array}$ & & $\begin{array}{l}\text { Fire procedure and range } \\
\text { information indication }\end{array}$ \\
\hline & $\begin{array}{l}\text { Equipment } \\
\text { integrated linkage } \\
\text { control logic } \\
\text { relationship }\end{array}$ & & $\begin{array}{l}\text { Fire elevator linkage } \\
\text { control }\end{array}$ \\
\hline & $\begin{array}{l}\text { Complex area } \\
\text { evacuation off - line } \\
\text { guidance } \\
\text { instructions }\end{array}$ & & \\
\hline \multirow{2}{*}{$\begin{array}{c}\text { Fire } \\
\text { extinguishing } \\
\text { linkage control }\end{array}$} & $\begin{array}{l}\text { Fire extinguishing } \\
\text { system linkage } \\
\text { control equipment } \\
\text { selection }\end{array}$ & & \\
\hline & $\begin{array}{l}\text { Fire control system } \\
\text { linkage control } \\
\text { logic relationship }\end{array}$ & & \\
\hline
\end{tabular}

\section{Comprehensive Evaluation of Design Performance of Automatic Fire Alarm System}

This paper evaluates the design performance of a university automatic fire alarm system and uses SPSS16.0 and Microsoft Excel to complete the data statistics and analysis process.

Expert Scoring. In the quantitative process of the indicators used in the expert scoring method. 
The evaluation process used the five-point principle to score the actual performance of the 21 indicators by four experts. The meanings of the individual values are as follows.

Table 2. Expert scoring table

\begin{tabular}{c|c|c|c|c|c}
\hline Fraction & 1 & 2 & 3 & 4 & 5 \\
\hline Implication & Not good & Just so & Commonly & Better & Splendidly \\
\hline
\end{tabular}

Index Data Operation. In SPSS16.0, enter the expert scoring data, and standardize the data of each index, the results shown in Table 3.

Table 3. Data standardization

\begin{tabular}{c|c|c|c|c|c|c|c|c|c|c}
\hline $\mathrm{Zx1}$ & $\mathrm{Zx} 2$ & $\mathrm{Zx3}$ & $\mathrm{Zx} 4$ & $\mathrm{Zx} 5$ & $\mathrm{Zx6}$ & $\mathrm{Zx7}$ & $\mathrm{Zx} 8$ & $\mathrm{Zx9}$ & $\mathrm{Zx10}$ & $\mathrm{Zx11}$ \\
\hline 0.000 & 1.225 & 1.095 & 0.000 & 1.500 & 0.993 & 1.225 & 1.391 & 0.500 & 0.500 & 1.391 \\
\hline 0.000 & -1.225 & 0.548 & 1.225 & -0.500 & 0.199 & 0.000 & -0.199 & 0.500 & 0.500 & -0.993 \\
\hline 1.225 & 0.000 & -0.548 & 0.000 & -0.500 & -1.391 & 0.000 & -0.993 & 0.500 & -1.500 & -0.199 \\
\hline-1.225 & 0.000 & -1.095 & -1.225 & -0.500 & 0.199 & -1.225 & -0.199 & -1.500 & 0.500 & -0.199 \\
\hline $\mathrm{Zx12}$ & $\mathrm{Zx13}$ & $\mathrm{Zx14}$ & $\mathrm{Zx15}$ & $\mathrm{Zx16}$ & $\mathrm{Zx17}$ & $\mathrm{Zx18}$ & $\mathrm{Zx19}$ & $\mathrm{Zx20}$ & $\mathrm{Zx21}$ & \\
\hline-0.500 & -0.866 & -0.866 & 0.000 & -1.225 & 0.866 & -0.783 & -1.225 & 1.225 & -0.866 & \\
\hline 1.500 & -0.866 & -0.866 & 1.225 & 1.225 & 0.866 & 0.261 & 1.225 & 0.000 & 0.866 & \\
\hline-0.500 & 0.866 & 0.866 & 0.000 & 0.000 & -0.866 & -0.783 & 0.000 & -1.255 & -0.866 & \\
\hline-0.500 & 0.866 & 0.866 & 1.225 & 0.000 & -0.866 & 1.306 & 0.000 & 0.000 & 0.866 & \\
\hline
\end{tabular}

$\mathrm{X} 1$ is the system basic technical requirements, $\mathrm{X} 2$ for the system network configuration and management mode, $\mathrm{X} 3$ is system compatible, $\mathrm{X} 4$ for the controller capacity redundancy and expansion, $\mathrm{X} 5$ for the fire detector selection and selection, $\mathrm{X} 6$ for the fire trigger device settings, X8 for the evacuation linkage control equipment selection, $\mathrm{X} 8$ for the fire alarm and emergency broadcast design, X9 for the evacuation channel equipment integrated linkage control logic, X10 for the personnel-intensive complex regional evacuation route guidance instructions, X11 fire extinguishing system linkage control equipment selection, X12 Fire protection system linkage control logic, X13 for the fire separation control equipment selection, X14 for the fire separation equipment linkage control relationship, X15 for the smoke control and smoke control valve monitoring, X16 for the evacuation channel fire door monitoring, X17 for the fire extinguishing equipment Monitoring, X18 for the scene fire power monitoring, X19 fire process and scope information instructions, X20 for the fire danger parts instructions, X21 for the fire elevator linkage control.

It is possible to judge whether the research project is suitable for principal component analysis by analyzing the correlation coefficient matrix. If there is a strong correlation between the variables (correlation coefficient greater than 0.5 that there is a strong correlation), you can analyze the main data, as shown in Table 4.

As can be seen from Table 5, x3 system compatibility, x5 fire detector selection and selection, $\mathrm{x} 7$ evacuation linkage control equipment selection, x8 fire alarm and emergency broadcast design, x17 fire protection facility monitoring, x20 fire hazard location indication and There is a large positive correlation between the main components, x13 fire separation control equipment selection, x14 fire separation equipment linkage control logic relationship and the first principal component has a 
greater negative correlation. X4 fire capacity and expansion of the controller, $\mathrm{x} 12$ fire control system linkage control logic relationship, x15 smoke exhaust fan and smoke control valve monitoring, x16 evacuation channel fire door monitoring, x19 fire process and range information indication and the second main component Big positive correlation. X2 system network composition and management mode and the second principal component has a greater negative correlation. X10 staff-intensive complex regional evacuation route guidance instructions, x18 field fire power monitoring and the third principal component has a greater positive correlation, $\mathrm{x} 1$ system basic technical requirements and the third principal component has a greater negative correlation.

Table 4. Correlation coefficient matrix

\begin{tabular}{|c|c|c|c|c|c|c|c|c|c|}
\hline & $x 1$ & $x 2$ & $x 3$ & $x 4$ & $\times 5$ & $\times 6$ & $\times 7$ & $x 8$ & $\times 9$ \\
\hline$x 1$ & 1.000 & .000 & .224 & .500 & .000 & $\cdot .649$ & .500 & -.324 & .816 \\
\hline$\times 2$ & .000 & 1.000 & .224 & .500 & .816 & .324 & .500 & .649 & .000 \\
\hline$\times 3$ & .224 & .224 & 1.000 & .671 & .730 & .580 & .894 & .725 & .730 \\
\hline$x 4$ & .500 &. .500 & .671 & 1.000 & .000 & .000 & .500 & .000 & .816 \\
\hline$\times 5$ & .000 & .816 & .730 & .000 & 1.000 & .662 & .816 & .927 & .333 \\
\hline$\times 6$ & -649 & .324 & .580 & .000 & .662 & 1.000 & .324 & .895 &,- 132 \\
\hline$x 7$ & .500 & .500 & .894 & .500 & .816 & .324 & 1.000 & .649 & .816 \\
\hline$x 8$ & -324 & .649 & .725 & .000 & .927 & .895 & .649 & 1.000 & .132 \\
\hline$\times 9$ & .816 & .000 & .730 & .816 & .333 & $\cdot .132$ & .816 & .132 & 1.000 \\
\hline$x 10$ & -816 & .000 & .365 & .000 & .333 & .927 & .000 & .662 & $\cdot .333$ \\
\hline$x 11$ & .000 & .973 & .435 & -.324 & .927 & .474 & .649 & .789 & .132 \\
\hline$x 12$ & .000 & -.816 & .365 & .816 & $\cdot .333$ & .132 & .000 & $\cdot .132$ & .333 \\
\hline$x 13$ & .000 & .000 & -.949 & -.707 & -.577 & -.688 & -.707 & -.688 & -.577 \\
\hline$x 14$ & .000 & .000 & -.949 & -.707 & -.577 & $\cdot .688$ & -.707 & $\cdot .688$ & $\cdot .577$ \\
\hline$x 15$ & .500 & -.500 & .671 & 1.000 & .000 & .000 & .500 & .000 & .816 \\
\hline$x 16$ & .000 & -1.000 & -.224 & .500 & -816 & -324 & -.500 & -649 & .000 \\
\hline$\times 17$ & .000 & .000 & .949 & .707 & .577 & .688 & .707 & .688 & .577 \\
\hline$x 18$ & -853 & -.426 & -.572 & -.426 & -.522 & .208 & -.853 & -.208 & -.870 \\
\hline$\times 19$ & .000 & -1.000 & -.224 & .500 & -.816 & -.324 & -.500 & -649 & .000 \\
\hline$\times 20$ & .500 & .500 & .671 & .000 & .816 & .973 & .500 & .973 & .000 \\
\hline$\times 21$ & -.707 & -.707 & -.316 & .000 & -.577 & .229 & -.707 & -.229 & -.577 \\
\hline
\end{tabular}

Table 5. Load table

\begin{tabular}{|l|r|r|r|}
\hline x1 & .011 & .028 & -.194 \\
x2 & .062 & -.121 & -.019 \\
x4 & .099 & .058 & -.013 \\
x5 & .036 & .133 & -.061 \\
x6 & .101 & -.051 & .006 \\
x7 & .074 & .000 & .145 \\
x8 & .098 & .012 & -.080 \\
x9 & .097 & -.030 & .076 \\
x10 & .059 & .070 & -.137 \\
x11 & .042 & .025 & .180 \\
x12 & .081 & -.099 & -.010 \\
x13 & .000 & .147 & .037 \\
x14 & -.087 & -.083 & -.037 \\
x15 & -.087 & -.083 & -.037 \\
x16 & .036 & .133 & -.061 \\
x17 & -.062 & .121 & .019 \\
x18 & .087 & .083 & .037 \\
x19 & -.062 & .003 & .162 \\
x20 & -.062 & .121 & .019 \\
x21 & .088 & -.016 & .114 \\
\hline & -.052 & .066 & .151 \\
\hline
\end{tabular}


In Figure 1, each axis represents a principal component, each indicator in this three-dimensional space has a certain location, according to the indicators in the three-dimensional map of the location can clearly see the importance of the indicators. If an indicator has no effect on the three principal components, it is at the origin of the coordinates; if an indicator has a large negative impact on the three principal components, it is far from the origin; if one Indicators have a positive effect on the three principal components, and it is far from the origin.

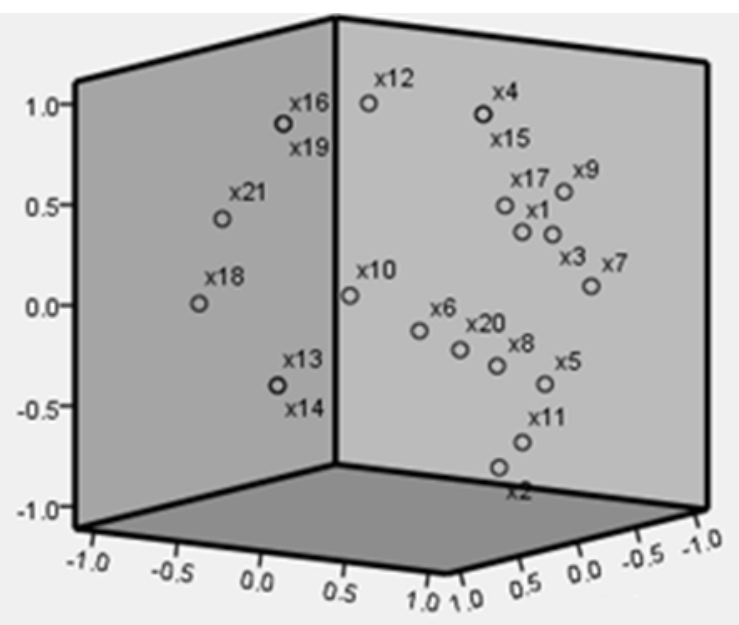

Figure 1. Component diagram

Design Performance Evaluation. After the analysis of the selection of the three principal components, the main component of the score can represent the entire system score. The linear combination of the three principal component coefficients is shown in equations (1), (2) and (3), and the principal component is shown in equation (4).

$\mathrm{F} 1=0.098 * \mathrm{Zx} 1+0.578 * \mathrm{Zx} 2+0.920 * \mathrm{Zx} 3+0.333 * \mathrm{Zx} 4+0.940 * \mathrm{Zx} 5+0.681 * \mathrm{Zx} 6+0.911 * \mathrm{Zx} 7+0.901 * \mathrm{Zx}$
$8+0.548 * \mathrm{Zx} 9+0.387 * \mathrm{Zx} 10+0.749 * \mathrm{Zx} 11+(-0.04) * \mathrm{Zx} 12+(-0.810) * \mathrm{Zx} 13+(-0.810) * \mathrm{Zx} 14+0.333 * \mathrm{Zx} 1$
$5+(-0.578) * \mathrm{Zx} 16+0.810 * \mathrm{Zx} 17+(-0.575) * \mathrm{Zx} 18+(-0.578) * \mathrm{Zx} 19+0.813) * \mathrm{Zx} 20+(-0.478) * \mathrm{Zx} 21$

$\mathrm{F} 2=0.185 * \mathrm{Zx} 1+(-0.810) * \mathrm{Zx} 2+0.388 * \mathrm{Zx} 3+0.891 * \mathrm{Zx} 4+(-0.341) * \mathrm{Zx} 5+0.000 * \mathrm{Zx} 6+0.080 * \mathrm{Zx} 7+(-0.2$ $03) * \mathrm{Zx} 8+0.472 * \mathrm{Zx} 9+0.170 * \mathrm{Zx} 10+(-0.661) * \mathrm{Zx} 11+0.983 * \mathrm{Zx} 12+(-0.556) * \mathrm{Zx} 13+(-0.556) * \mathrm{Zx} 14+0$. 891*Zx15+0.810*Zx16+0.556*Zx17+0.020*Zx18+0.810*Zx19+(-0.104)*Zx20+0.442*Zx21

$\mathrm{F} 3=(-0.978) * \mathrm{Zx} 1+(-0.095) * \mathrm{Zx} 2+(-0.063) \mathrm{Zx} 3+(-0.310) * \mathrm{Zx} 4+0.030 * \mathrm{Zx} 5+0.732 * \mathrm{Zx} 6+(-0.405) * \mathrm{Zx} 7$ $+0.384 * \mathrm{Zx} 8+(-0.691) * \mathrm{Zx} 9+0.906 * \mathrm{Zx} 10+(-0.050) * \mathrm{Zx} 11+0.185 * \mathrm{Zx} 12+(-0.186) * \mathrm{Zx} 13(-0.186) * \mathrm{Zx} 1$ $4+(-0.310) * Z x 15+0.095 * Z x 16+0.186 * Z x 17+0.818 * Z x 18+0.095 * Z x 19+0.573 * Z x 20+0.759 * Z x 21$

$$
\mathrm{F}=9.266 /(9.266+6.694+5.04) * \mathrm{~F} 1+6.694 /(9.266+6.694+5.04) * \mathrm{~F} 2+5.04 /(9.266+6.694+5.04) * \mathrm{~F} 3
$$

Through the calculation of the four experts for the three main components of the score, and then through the three principal component score obtained a comprehensive score, four experts get the final score is the final result of the final evaluation of the system, combined with four experts Comments, the final score was 3.15 points. Then the expert evaluation of the fire automatic alarm system design performance is excellent.

\section{Conclusion}

This paper analyzes the evaluation indexes of system design performance comprehensively and quantifies and standardizes them. And then the principal component analysis, the three principal components F1, F2, F3, the three principal components through the index of the score matrix distribution, the three main components of the score, and calculated a comprehensive score, automatic fire alarm system Design performance is excellent. 


\section{Acknowledgement}

In this paper, the research was sponsored by College students training program of innovation and entrepreneurship in Shenyang Aerospace University (DS504101).

\section{References}

[1] Z. G. Liu. Investigation on the Performance of Fire Detection Systems for Tunnel Applications-Part 2: Full-Scale Experiments under Longitudinal Airflow Conditions [J]. Fire Technology, 2011, 47: 191-220

[2] Marty Ahrens. Smoke Alarm Presence and Performance in U.S. Home Fires [J]. Fire Technology, 2011, 47:699-720

[3] Zhang Zhenna, Zhang Qin. Performance Study on Fire Alarm System in Large Space Buildings [J]. Recent Advances in Computer Science and Information Engineering, 2012,1: 69-73

[4] Zhang_Limin. Research on the Efficiency Evaluation Model of Fire Command Automation System [J]. Advanced Materials Research, 2012, 383-390: 2492-2495

[5] G. Santha Kumari and K. Narasimha Rao. Preliminary Level Automated Classification of Brain Tumor Using PCA and PNN[J]. International Journal of Advanced Research in Computer Science and Software Engineering,2014,11 